Governors State University OPUS Open Portal to University Scholarship

Faculty Research and Creative Activity

2002

\title{
An Additional Source of Data on Northeastern Illinois Woodlands around the Time of Settlement
}

Jon Mendelson

Follow this and additional works at: http://opus.govst.edu/faculty

Part of the Life Sciences Commons, Natural Resources and Conservation Commons, and the Natural Resources Management and Policy Commons

\section{Recommended Citation}

Mendelson, Jon. 2002. An additional source of data on northeastern Illinois woodlands around the time of settlement. American Midland Naturalist, 147:279-286.

This Article is brought to you for free and open access by OPUS Open Portal to University Scholarship. It has been accepted for inclusion in Faculty Research and Creative Activity by an authorized administrator of OPUS Open Portal to University Scholarship. For more information, please contact opus@govst.edu. 


\title{
An Additional Source of Data on Northeastern Illinois Woodlands around the Time of Settlement
}

\author{
JON MENDELSON \\ Science Division, Governors State University, University Park, Illinois, 60466
}

\begin{abstract}
A new source of data on early postsettlement woodlands, witness trees in woodlot subdivision surveys, is described. Subdivision surveys of Thorn Grove, Will County, Illinois (1848-1856), using 92 witness trees, are compared to the presettlement 1834 Public Land Survey (PLS) including the same area. The woodland described in the subdivision surveys was richer in species, lower in density and composed of smaller trees than the woodland described in the PLS. Decreased density and tree size suggest beginning deforestation, but surveyor bias is a possibility.
\end{abstract}

\section{INTRODUCTION}

Public Land Survey (PLS) notes have, up to now, been our only source of quantitative information on the presettlement forest. Attention has focused on using increasingly sophisticated tools [DECORANA (Bowles et al., 1994), and spatial techniques associated with geographic information systems (Compas and Batek, 1994; Manies and Mladenoff, 2000)] to analyze this data source. Another source of data on the woodlands of the period does exist, raising the possibility of increasing many times the information available on species composition, size distribution and density of these early forests. The data are found in the surveys subdividing the original forests into woodlots. Single trees were used to witness lot corners, and the same information was recorded as in the PLS (species, size and distance from the survey point), thus, permitting the same kind of quantitative analysis. Since the lots were small [ 5 to 40 acres ( 2 to $16 \mathrm{ha}$ )] a subdivision less than a quarter section, for example, can yield data on a large number of trees. Since the subdivisions lay in areas between section lines, it should be possible to discern patterns in section interiors that the widely spaced points of the PLS could not detect.

Subdividing woodlands into small parcels was apparently widespread in northern and central Illinois. Fuller (1923) mentions it in discussing the prairie-forest border in LaSalle County. Mendelson (1998) reprinted a map of the woodlands along Plum Creek in Crete Township, Will County, subdivided by 1873 into numerous woodlots. It is not known how many of these subdivisions used trees to witness lot corners, but it is likely that this practice was widespread. In Will County subdivision surveys using witness trees have been located for the woodlands along the DuPage River in DuPage, Wheatland and Plainfield townships (Will County Surveyors Record. Book 1, 1835-1839), Messenger Woods in Homer Township (Book 1, 1835-1839) and Thorn Creek Woods in Crete and Monee townships (Book 7, Part 1, 1847-1856). The subdivision surveys date from 1835 until at least 1856, as compared with the Will County PLS dates, 1821 to 1834 .

In this article surveys of seven subdivisions in Thorn Creek Woods are examined. Thorn Creek Woods, originally about 1000 ha, is the Will County portion of a much larger woodland, Thorn Grove, which extended well into Cook County. Comparisons are made between forest structure and composition determined from the subdivision surveys and that obtained from the PLS, which took place for both the Will and Cook county portions of Thorn Grove in 1834. Settlement of the Thorn Grove area is variously put at 1833 (Woodruff et al., 1878), 


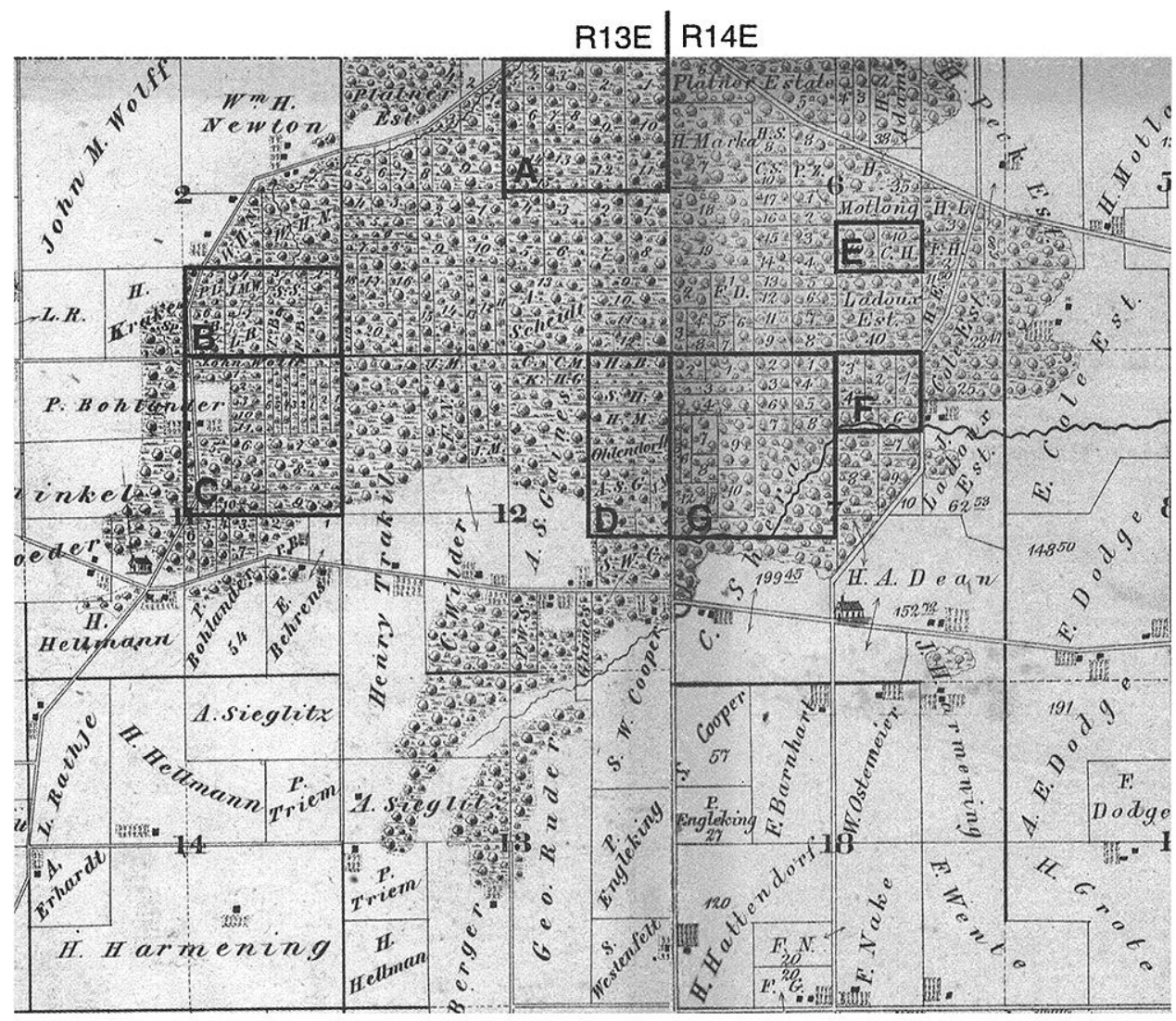

Fig. 1.-Composite 1873 plat map of portions of Monee and Crete townships, Will County, Illinois, showing Thorn Grove subdivided into many small woodlots (Thompson Brothers and Burr, 1873). The seven 1848-1856 subdivisions are designated A-G. See Table 1 for further information on these subdivisions

or 1834 (Milne, 1973), coincident with the PLS. The seven woodlot subdivisions were surveyed from 1848-1856, 14 to 22 y after the PLS.

\section{METHODS}

Subdivision surveys. - A plat map of the Will County portion of Thorn Grove shows the locations of the subdivisions (Fig. 1). The plat is from 1873 by which time Thorn Grove had been subdivided into well over 100 lots. The location, size, number of witness trees, date surveyed and reference in the survey records for Will County are shown for each of the seven subdivision surveys (Table 1). The total area surveyed was 267 ha, with 92 trees used to witness lot corners. As examples, plat maps of two of these subdivisions, one from Monee Township and one from Crete Township are presented, showing the species, size and location of witness trees (Figs. 2, 3).

Comparisons with the 1834 Public Land Survey.-Three comparisons are made between 
TABLE 1.-Subdivision surveys of 1848-56 in Thorn Creek Woods, Will County, Illinois. Documents are located in the archives of the Will County Recorder of Deeds. Letters A-G refer to locations of subdivisions in Figure 1

\begin{tabular}{|c|c|c|c|c|c|c|}
\hline & Section & Location & $\begin{array}{l}\text { Size, acres } \\
\text { (hectares) }\end{array}$ & $\begin{array}{l}\text { \# of } \\
\text { Trees }\end{array}$ & Date & Reference \\
\hline \multicolumn{7}{|c|}{ T 34 N., R 13 E., Monee Township } \\
\hline A & 1 & $\mathrm{NE} 1 / 4$ & $128(51)$ & 14 & 1856 & Plat Book 2, Book 2: 77 \\
\hline B & 2 & $\mathrm{~S}^{1 / 2}$ of $\mathrm{SE} 1 / 4$ & $80(32)$ & 15 & 1850 & Surveyor's Records: Book 7, Part 1: 76-77 \\
\hline $\mathrm{C}$ & 11 & $\mathrm{NE} 1 / 4$ & $160(64)$ & 19 & 1850 & Book 7, Part 1: 83 \\
\hline $\mathrm{D}$ & 12 & $\mathrm{E}^{1 / 2}$ of NE $1 / 4$ & $80(32)$ & 9 & 1848 & Book 7, Part 1:28 \\
\hline \multicolumn{7}{|c|}{ T 34 N., R 14 E., Crete Township } \\
\hline $\mathrm{E}$ & 6 & $\mathrm{SE} 1 / 4$ & $20(8)$ & 6 & 1848 & Book 7, Part 1: 28 \\
\hline $\mathrm{F}$ & 7 & NW $1 / 4$ of NE $1 / 4$ & $40(16)$ & 9 & 1848 & Book 7, Part 1: 30 \\
\hline G & 7 & NW $1 / 4$ & $160(64)$ & 20 & 1848 & Book 7, Part 1: 28-29 \\
\hline
\end{tabular}

the PLS and the subdivision surveys: species composition, size distribution of oaks (Quercus spp.) and estimates of density. For the PLS, only data from the Will County portion of Thorn Grove are used, since these are more directly comparable with data from the subdivision surveys. The PLS maps of Crete and Monee townships showing the perimeter of Thorn Grove and the location of survey points are found in Plats of Will County Field

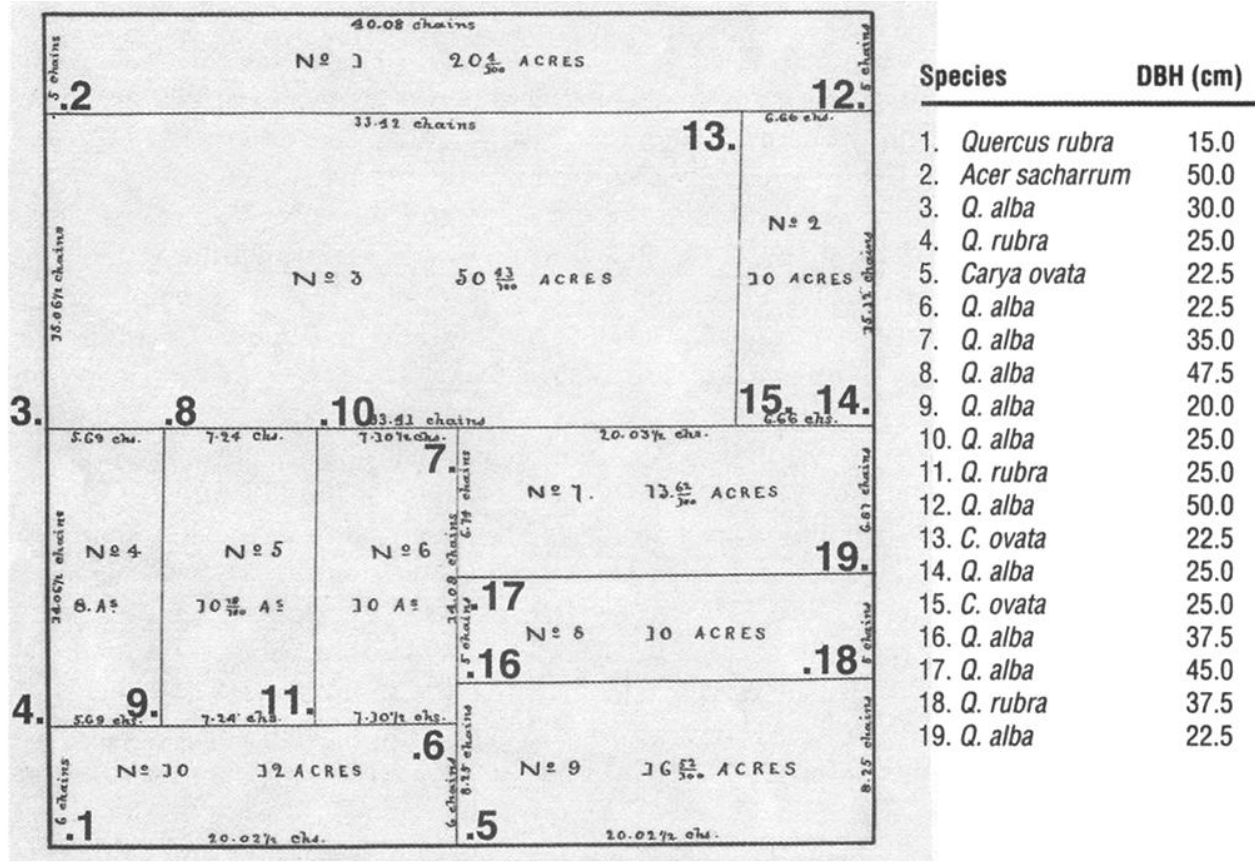

FIG. 2.-Plat of the NE $1 / 4$ of Section 11, T 34 N., R.13 E. (Monee Township) in 1850. Location of witness trees taken from survey notes. Distance of trees to lot corners not to scale 


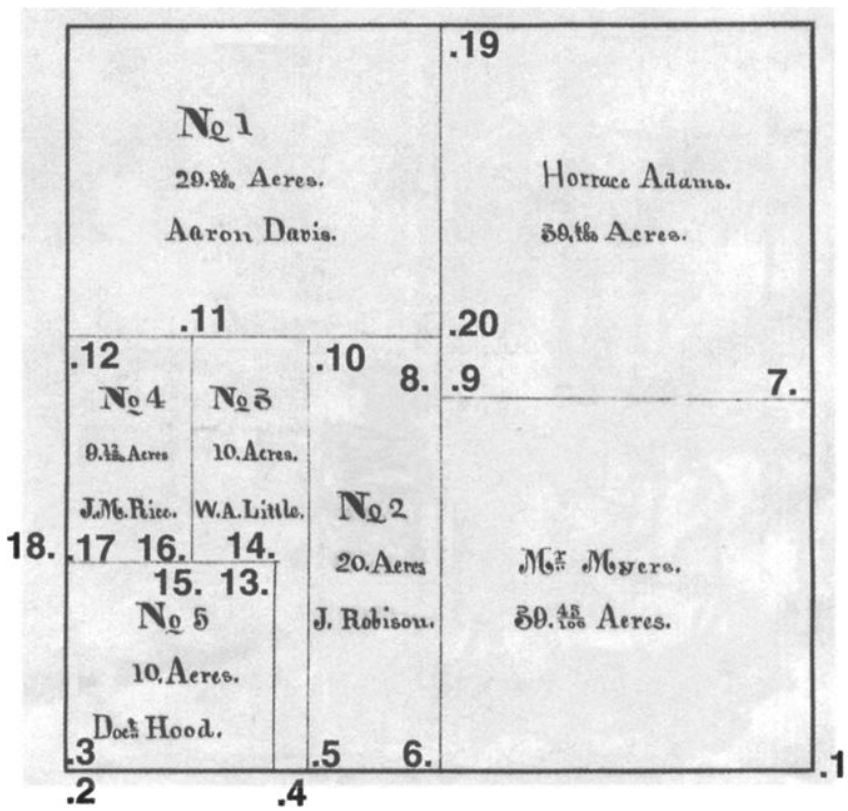

1. Quercus alba 22.5

2. Q. alba 20.0

3. Q. "spanish" $\quad 30.0$

4. Q. alba 37.5

5. Q. alba $\quad 15.0$

6. Q. "yellow" $\quad 47.5$

7. Fraxinus $s p$. $\quad 35.0$

8. Ostrya virginana 20.0

9. Q. "spanish" 35.0

10. Q. alba $\quad 50.0$

11. Q. macrocarpa 35.0

12. Q. macrocarpa 22.5

13. Q. alba 25.0

14. Q. spanish $\quad 30.0$

15. Fraxinus $s p$. $\quad 32.5$

16. Q. "spanish" $\quad 40.0$

17. Carya ovata 25.0

18. Q. "spanish" 22.5

19. Q. alba $\quad 50.0$

20. Q. alba $\quad 45.0$

FIG. 3.-Plat of the NW $1 / 4$ of Section 7, T 34 N., R.14 E. (Crete Township) in 1848. Location of witness trees taken from survey notes. Distance of trees to lot corners not to scale

Notes, Volume 14, p. 17 and 18, respectively. The PLS notes for the two townships are found in Field Notes of Will County Surveys, Volume 5, Parts 1 and 2. There were 14 PLS points within this part of Thorn Grove, four section corners and 10 quarter section points. A point is defined as within the forest if it followed the phrase "enter timber" or preceded "leave timber" in the survey notes. In the 1834 PLS four trees were used to witness a section corner and two to witness a quarter section. In all, 36 witness trees were employed. In addition, 22 line trees were also noted in the PLS. Both witness and line trees are used in determining species composition and size distribution. Only witness trees are used in density estimates.

Differences in species composition between the PLS and the subdivision surveys are evaluated by percent similarity, $\mathrm{C}_{\%}$ (Cox, 1996). Differences between the PLS and the subdivision surveys in the size distribution of oaks are tested for significance using chi square with $\alpha=0.05$. Density is estimated for both the PLS and the subdivision surveys by the Quarter Method (Cottam and Curtis, 1956). Each of the PLS points is treated as a sample of $n=$ 4 or $\mathrm{n}=2$. In the latter case, the correction factor $\Sigma$ point-plant distance/1.31 is used. For the subdivision surveys the density estimates for each of the seven surveys is treated as a separate sample of size $\mathrm{n}$ (Table 1 ). Since only a single tree was located at each point, the correction factor $\Sigma$ point-plant distance/ $0.5 \mathrm{n}$ is used. In a few cases, two trees were used to witness a corner (Fig. 3). Here the closer of the two is treated as if it were the lone tree. Differences between the PLS and the subdivision surveys in the distributions of density are evaluated for significance by the Mann-Whitney $U$ test with $\alpha=0.05$. Mann-Whitney is a rank order test using, in this case, the combined 21 density estimates. 
TABLE 2.-Percent composition of trees in the PLS (1834) and subdivision surveys (1848-56). The PLS sample consists of all witness and line trees from the Will County portion of Thorn Grove in Crete and Monee townships. The subdivision survey sample is composed of all trees witnessing lot corners in these same townships. Common names used in the surveys are in parentheses

\begin{tabular}{|c|c|c|}
\hline \multirow[b]{2}{*}{ Species } & \multicolumn{2}{|c|}{$\%$ Density } \\
\hline & $\begin{array}{c}\text { PLS } \\
(n=58)\end{array}$ & $\begin{array}{c}\text { Subdivisions } \\
\quad(n=92)\end{array}$ \\
\hline Acer saccharum (Sugar tree) & - & 1.1 \\
\hline Carya ovata (Hickory) & 8.6 & 7.5 \\
\hline Fraxinus spp. (Ash) & - & 2.2 \\
\hline Juglans nigra (Black walnut) & - & 1.1 \\
\hline Ostrya virginiana (Ironwood) & - & 1.1 \\
\hline Quercus alba (White oak) & 58.6 & 45.7 \\
\hline Q. macrocarpa (Bur oak) & 10.3 & 15.2 \\
\hline Q. rubra $($ Red oak $)$ & 3.5 & 4.3 \\
\hline Q. velutina (Black oak) & 8.6 & 3.3 \\
\hline Q. sp. (Spanish oak $)^{1}$ & 6.9 & 8.7 \\
\hline Q. sp. $(\text { Yellow oak })^{2}$ & 3.5 & 7.6 \\
\hline Tilia americana (Lynn) & - & 1.1 \\
\hline Ulmus sp. (Elm) & - & 1.1 \\
\hline
\end{tabular}

${ }^{1}$ Possibly Q. ellipsoidalis

${ }^{2}$ Probably Q. muhlenbergii

\section{RESULTS}

Species composition.- - Seven species were recorded in the PLS; 13 were recorded in the subdivison surveys including all of those found in the PLS (Table 2). The added species, sugar maple (Acer saccharum), ash (Fraxinus sp.), black walnut (Juglans nigra), ironwood (Ostrya virginiana), basswood (Tilia americana) and elm (Ulmus sp.) are generally associated with mesic woodlands. These species were rare in the subdivision surveys. Both the PLS and the subdivision surveys were heavily oak dominated. This is reflected in the percent similarity, $\mathrm{C}_{\%}=80.7$ between the two.

The PLS and the subdivision surveys each recorded the same six species of oak. The identities of four species, white (Quercus alba), black ( $Q$. velutina), bur ( $Q$. macrocarpa) and red ( $Q$. rubra) oak, are not in doubt. Yellow oak is probably $Q$. muhlenbergii, which is still found in limited numbers in Thorn Creek Woods today (Solecki and Taft, 1986). Spanish oak is the common name of $Q$. falcata, the range of which is far south of Thorn Grove (Burns and Honkala, 1990). A more likely possibility is Q. ellipsoidalis (Hill's oak), which is common in present day Thorn Creek Woods.

The overall proportion of oaks was slightly lower in the subdivision surveys $(84.8 \%)$ than in the PLS (91.4\%). This difference was due almost entirely to white oak, whose relative density was $12.9 \%$ lower in the subdivision surveys than in the PLS (Table 2). Four of the other five oak species had higher relative densities in the subdivision surveys than in the PLS.

Size distribution of the oaks. - The size distributions of the oaks were significantly different between the PLS and the survey subdivisions $\left(\chi^{2}=32.3\right.$, df $\left.=2, \mathrm{P}<0.01\right)$. There were more large trees in the PLS, more small ones in the subdivision surveys (Table 3 ). In the PLS, over $45 \%$ of the oaks chosen as witness trees or noted as line trees were $\geq 45 \mathrm{~cm}$ in $\mathrm{dbh}$. In the subdivision surveys, oaks $\geq 45 \mathrm{~cm}$ in dbh made up fewer than $20 \%$ of witness 
TABLE 3.-Size distribution of Quercus spp. in the PLS (1834) and subdivision surveys (1848-56). The PLS sample consists of all witness and line oaks from the Will County portion of Thorn Grove in Crete and Monee townships. The subdivision survey sample is composed of all oaks witnessing lot corners in these same townships

\begin{tabular}{lcc}
\hline \hline & & \% Total \\
\cline { 2 - 3 } DBH class $(\mathrm{cm})$ & PLS & Subdivisions \\
$(n=53)$ & $77)^{1}$ \\
\hline$<15.0$ & - & 7.8 \\
$15.0-29.9$ & 18.8 & 36.4 \\
$30.0-44.9$ & 34.0 & 37.6 \\
$45.0-59.9$ & 39.6 & 15.6 \\
$\geq 60.0$ & 7.5 & 2.6 \\
\hline
\end{tabular}

${ }^{1}$ There were actually 78 oaks recorded; one white oak was not sized

trees. Conversely, more than $44 \%$ of the subdivision trees were $<30 \mathrm{~cm}$ in $\mathrm{dbh}$, compared to fewer than $20 \%$ of witness and line trees in the PLS. Nonetheless, in both the PLS and the subdivision surveys a broad range of sizes were represented.

Density estimates. - The PLS estimates of density showed considerable variability, ranging from 3.1 trees/ha at a woodland edge to well over 200 trees/ha at a more interior point. Nevertheless, the distributions of density estimates were significantly different between the PLS and the subdivision surveys (Mann-Whitney U test, $\mathrm{P}<0.05$ ). The PLS density estimates were stochastically larger than those of the subdivision surveys. Over $70 \%$ of the PLS estimates were of 50 or more trees/ha, with four of the 14 points $(28.6 \%)$ estimating $\geq 100$ trees/ha (Table 4$)$. In contrast, only one of the seven subdivision samples $(14.3 \%)$ had an estimate of more than 50 trees/ha.

\section{Discussion}

There were differences between the quantitative descriptions of Thorn Grove extracted from the PLS of 1834 and those of the postsettlement subdivision surveys. In this analysis the woodland of the subdivision surveys was richer in species, with a slightly reduced oak

TABLE 4.-Density estimates for the PLS (1834) and subdivision surveys (1848-56). The PLS estimates consist of 14 samples, 4 section corners $(n=4)$ and 10 quarter sections $(n=2)$. The subdivision survey estimates are from the 7 subdivisions, each treated as a separate sample unit with $n$ sizes 14,15 , $19,9,6,8^{1}$, and $15^{2}$ respectively

\begin{tabular}{lrc}
\hline \hline \multirow{2}{*}{$\begin{array}{c}\text { Estimated } \\
\text { trees/ha }\end{array}$} & PLS & \% Estimates \\
\cline { 2 - 3 }$<50$ & 28.6 & Subdivisions \\
$50-99$ & 42.9 & 85.7 \\
$100-149$ & 7.1 & 14.3 \\
$150-199$ & 7.1 & - \\
$\geq 200$ & 14.3 & - \\
\hline
\end{tabular}

${ }^{1}$ There was one lot corner witnessed by two trees in this subdivision. The closer of the two was used in the density estimate

${ }^{2}$ There were five lot corners witnessed by two trees in this subdivision. In each case the closer of the two was used in the density estimate 
presence, and consisted of smaller, more widely spaced trees than the woodland described in the PLS.

With respect to species composition, almost twice as many species were mentioned in the subdivision surveys suggesting not only greater species richness than the PLS detected, but also a mesic component to Thorn Grove that was not apparent in the PLS. The presence of mesic species in the subdivision surveys was partly a function of topographic location: two of the subdivisions in Monee Township with 34 witness trees lay in the valleys of Thorn Creek and its immediate tributaries, the most mesic habitats within Thorn Grove (Figs. 1B, C). It was in these subdivision surveys that sugar maple, black walnut, basswood and elm were used as witness trees. In contrast, only a single PLS quarter section point fell in the Thorn Creek valley. The only hints of a mesic component in the PLS were the choice of red oaks as the witness trees for this point, and the surveyor's comment, "land very well timbered."

It should be pointed out that the individuals of the additional species mentioned in the subdivision surveys were part of the presettlement forest. Many would have been of a size suitable for use as witness trees in the 1834 PLS. The single sugar maple, for example, was $50 \mathrm{~cm}$ in dbh in 1850; the one ironwood mentioned was $20 \mathrm{~cm}$ in dbh in 1848, large for this species. Based on age-size relationships in present day Thorn Creek Woods (Mendelson, 1994), both trees were probably well over 100 y old.

The other major difference was in percent composition: a smaller percentage of white oaks in the subdivision surveys $(45.7 \%)$ than in the PLS $(58.6 \%)$. This change may be an indication of early logging. White oak was the most valuable of the oaks to the early settlers (Peattie, 1966), and presumably would be among the first species to be cut.

Settlement of Thorn Grove was approximately coincident with the PLS (Woodruff et al., 1878; Milne, 1973). By the time of the earliest subdivision surveys, the periphery of the Grove had already been occupied for at least $14 \mathrm{y}$. The demand for wood during this period must have been substantial. It is not clear whether these early settlers owned the parcels later subdivided into woodlots, or whether they remained in public ownership. In any case, public ownership would not have made them immune to exploitation. This is suggested by a comment in an 1839 subdivision survey in DuPage Township: "The witness trees cut away" (Will County Surveyors Record Book 1: 1839: 100).

Comparison of the size distributions of the oaks revealed significantly more small individuals and fewer large ones used as witness trees in the subdivision surveys than in the PLS. This shift may be another indicator of the early stages of destruction of the presettlement forest, some proportion of the larger trees already having been cut by the time of the subdivision surveys.

In spite of differences in size distribution, all but the smallest and largest size classes were well represented in both the PLS and the subdivision surveys, suggesting that the presettlement forest may have been all-aged. This is in contrast to the strongly bimodal size distribution of oaks in present day Thorn Creek Woods, where trees are clustered in the large $(\geq 50 \mathrm{~cm} \mathrm{dbh})$ and small $(<30 \mathrm{~cm} \mathrm{dbh})$ size classes, representing an even-aged postsettlement canopy and a younger ( $\leq 60$ y) understory, respectively (Mendelson, 1994).

The significant difference in the distribution of density estimates, with a greater proportion of low density estimates ( $<50$ trees/ha) in the subdivision surveys than in the PLS, is also consistent with the interpretation of beginning removal of the presettlement canopy. These densities could, however, be systematic underestimates if surveyor bias were a factor. The subdivision lots were almost certainly intended for timber exploitation. This purpose could have influenced the selection of witness trees, for example, choosing trees less likely to be cut. Although beginning deforestation remains the most plausible explanation for 
reduced density estimates in the subdivision surveys, in the absence of further information, surveyor bias cannot be ruled out.

The high concentration of witness trees in relatively small areas is the most promising feature of the subdivision surveys, providing the opportunity for more detailed studies of forest structure than is possible from the PLS. Nevertheless, certain interpretive ambiguities remain. While the individual witness trees of the subdivision surveys, excepting possibly the very smallest, were of presettlement origin, the woodland as a whole seems to have been losing its presettlement character. It had become more open, with some portion of the larger trees already removed. To what extent presettlement conditions can be inferred from the subdivision surveys, therefore, remains an open question. It may be that the value of the subdivision surveys will lie primarily in documenting woodland changes in the early years of Euro-American occupancy.

Acknowledgments. - I would like to thank J. Larsen, W. Luft and B. Rupp who located many of these records. J. Ebinger, J. D. Mendelson, E. Miller, L. Randa and J. Yunger made helpful suggestions on this manuscript. S. Oliver did the figures.

\section{Literature Cited}

Bowles, M. L., M. D. HutChison AND J. L. MCBride. 1994. Landscape pattern and structure of oak savanna, woodland, and barrens in northeastern Illinois at the time of European settlement, p. 65-73. In: J. S. Fralish, R. C. Anderson, J. E. Ebinger and R. Szafoni (eds.). Proceedings of the North American Conference on Savannas and Barrens. U.S. Environmental Protection Agency, Great Lakes National Program Office, Chicago, Ill. 410 p.

Burns, R. M. And B. H. Honkala, Tech. COORdS. 1990. Silvics of North America: 2. Hardwoods. Agriculture Handbook 654. U.S. Department of Agriculture, Forest Service, Washington, D.C. Vol. 2, 877 p.

COMPAS, E. AND M. BATEK. 1994. Reconstructing the presettlement vegetation of the Current River watershed in Missouri. GIS/LIS, 174-180.

Cottam, G. AND J. T. CURTis. 1956. The use of distance measures in phytosociological sampling. Ecology, 37:451-460.

Cox, G. 1996. Laboratory Manual of General Ecology, 7th ed. Wm. C. Brown Publishers, Dubuque, Ia. $278 \mathrm{p}$.

$\rightarrow$ Fuller, G. D. 1923. An edaphic limit to the forests in the prairie region of Illinois. Ecology, 4:135-140.

MANIES, K. L. AND D. MLADENOFF. 2000. Testing methods to produce landscape-scale vegetation maps from U.S. Public Land Survey records. Landscape Ecol., 15:741-754.

Mendelson, J. 1994. Age structure of trees in Thorn Creek Woods, p. 103-6. In: J. S. Fralish, R. C. Anderson, J. E. Ebinger and R. Szafoni (eds.). Proceedings of the North American Conference on Savannas and Barrens. U.S. Environmental Protection Agency, Great Lakes National Program Office, Chicago, Ill. $410 \mathrm{p}$.

1998. Restoration from the perspective of recent forest history. Trans. Wisconsin Acad. of Sci., Arts, and Lett., 86:137-148.

Milne, M. M. 1973. Our roots are deep: a history of Monee, Illinois. Monee, Ill. 341 p.

PEATTIE, D. C. 1966. A natural history of trees. Houghton Mifflin, Boston, Mass. 606 p.

SOLECKI, M. K. AND J. TAFT. 1986. Thorn Creek Woods Nature Preserve Management Plan. Illinois Nature Preserves Commission, Springfield, Ill. 59 p.

THOMPSON BROTHERS, AND BURR, PUBL. 1873. Combination atlas map of Will County, Illinois; compiled, drawn and published from personal examinations and surveys. Thompson Brothers and Burr, Elgin, Ill. 139 p.

Woodruff, G. H., W. H. Perrin and H. H. Hill. 1878. History of Will County, Illinois. Wm. LeBaron Jr. and Co., Chicago, Ill. 973 p. 